\title{
Transformation of Educational Activity: Social and Philosophic Aspects
}

\author{
Valentina Maykova \\ Mytishchi Subsidiary \\ Bauman Moscow State Technical University \\ 1st Institutskaya Str. 1 \\ Mytishchi, Moscow Region, Russian Federation 141005 \\ E-mail: valmaykova@mail.ru
}

\author{
Eduard Molchan \\ Sergiyev Posad Branch \\ High School of Folk Arts (Academy) \\ Severnyy Proezd 5 \\ Sergiyev Posad, Moscow Region, Russian Federation \\ 141300 \\ E-mail: ed.molchan2015@yandex.ru
}

\author{
Vladimir Falko \\ Mytishchi Subsidiary \\ Bauman Moscow State Technical University \\ 1st Institutskaya Str. 1 \\ Mytishchi, Moscow Region, Russian Federation 141005 \\ E-mail: vfalco@yandex.ru
}

\begin{abstract}
The study deals with educational activity as the basis for solving the problems of contemporary education in the context of globalisation. Our research methodology is a social and philosophical analysis of educational activity problems. We attract attention to the existing contradictions between rationality and morality, virtuality and reality, transnational globalism and national cultures, all of which lead to conflicts and crises. Changes in the specifics of social development requires actualising the consolidating function of educational activity, fighting the dominance of mass culture, the reasons behind terrorism, environmental disasters and other global problems. We specify those properties of educational activity that ensure optimum interaction of all components of social development and stability of the social and natural system consisting of educational activity, the individual and social being. We validate the necessity of transforming educational activity into any other activity that deals with transferring knowledge and forming specific skills and abilities and transforms a standard type of activity into an individual activity style that consolidates the society. Transformation of educational activity into economic, political, environmental, scientific and other types of activity consolidates the society in the context of globalisation and ensures stable development on the global scale.
\end{abstract}

Keywords-educational activity; globalisation; individual; socialisation; informatisation of the society; education; education policy; principles of educational activity

\section{INTRODUCTION}

The issue of identifying education strategies over the course of contemporary civilisation processes is the matter of the social and cultural genotype of humanity, which may be defined as a program of historical deployment of those material forms that the intellectual activity takes. This program is established during antropo-sociogenesis of the previous human generations and is structurally determined by the social and cultural environment.

The social and cultural gene means an ideal form of activity, embodied on the material level in the signs and symbols characteristic of a given layer of culture. It encodes the semiotic information accumulated at a given stage of social evolution of the humankind, mastering which in a dialogic interaction forms the individual's objective properties of mentality, thought and consciousness that match the individual's age and development level [1].

The social and cultural gene aids in becoming aware of the processes of socialisation of the individual and whole generations and in perceiving and reproducing the spiritual and historic experience of the humankind. Civilisational development of nations should attest to the fact that the standing of education is improving. However, today a worldwide education crisis is believed to be taking place. The issues mentioned include lack of spirituality, devaluation of values, national nihilism, lack of professionalism, narrow specialisation, graduates' inability to adapt to the conditions of their society, debates between proponents of classical education and vocational training, limited human capabilities of mutual understanding and cooperation, and so on [2].

\section{CONTRADICTIONS IN EDUCATIONAL ACTIVITY AND THE ATTRIBUTES OF CONTEMPORARY CIVILISATION PROCESSES}

The contradictions between the education of today being aimed at the masses and the necessity of training elite specialists in scientific and engineering fields as well as in liberal arts, between curricula filled with abstract theory and 
economics and industry needing specific utilitarian knowledge, between STEM specialisations being in demand and young people not being that much interested in them have led to reforms and upgrades in education systems of many countries. It is obvious that every country has its own internal reasons for crises and other phenomena in education at a given stage of its historical development; however, there also exists a common reason behind this worldwide education crisis. According to contemporary researchers, this reason is the fact that education cannot meet new social and general human demands anymore. This means that we need to specify priority directions in education according to the requirements of the human being and the society.

The point of a philosophical investigation is always not to merely clarify those ideological structures that define the worldview and lifestyle in a given historical age, but also, by reflecting upon these structures, to propose possible options for new meanings of life and new values [3].

This concerns education as a social institution as well. The Enlightenment model of education has run its course. The world is on the verge of the necessity to radically revise the foundations of education policy. We can make out the outline of the new education paradigm already. Various authors state this idea, citing different arguments.

Education is not only the subject, but also the object of rethinking, modernisation and redesign. It should systematically transform itself, in terms of goal setting and methodology, content and technology, organisation and management, corresponding to the modern times.

A hallmark of contemporary civilisation processes in the world today is a balanced, well thought-out education system, featuring a selection method based on abilities of the individual. Manageability of the education system, existence of a dedicated service network and consultants armed with state-of-the-art technology, along with the presence of an efficient state-wide system and early pedagogic diagnostics are the main attributes of contemporary education models [4].

In the early 21 st century new social and economic conditions and informatisation of the society have led to a considerable increase in the needs of a human being related to his or her social role, general culture and education. The transition of today's society into the sixth wave of innovation makes the informatisation process an integral part of both the present and the future. The cybernetic revolution that started in the 1950s and is supposed to last up to the middle or the second half of this century is going to radically change the world.

Since this process entails introducing new technologies into the social being, it is accompanied by large-scale commercialisation, which requires analysing the problems, prospects and threats arising without doubt over the course of marketing and implementing breakthrough research.

Computer and digital revolutions use state-of-the-art technology and affect cognitive faculties of people. Information surrounds us, yet people hunger for more knowledge. Knowledge is deteriorating faster and quickly becoming obsolete. This process happens at different rates in various fields: from 1.5-2 years in the most sought-after sciences up to 15 years in fundamental, applied and even engineering knowledge [5]. Using antropo-computer systems and gadgets has changed the connections between the following cognition components: intellectual and rational, emotional and sensitive, intuitive; the determinants of cognitive activity imposed by the informational worldview have also transformed.

Education has changed its standing in the life of the society and the individual. Previously its main objective was to prepare a young person to a life in the industry; these days it should ensure a multifaceted preparation for all the various manifestations of life. Education should help a person realise his or her "self". It should provide a person with an opportunity to "be him- or herself", to "become", "selfactualise". Education is turning into educational services, whose sphere largely functions according to the laws of market. Firstly, this sphere comprises formal, extraformal and informal learning. Secondly, it displays a higher degree of autonomy. Education becomes a contractor of sorts providing service to customers: individuals, social groups, social institutions (including the state), and the society at large.

The sphere of educational services is a markedly broader phenomenon than the education system. It is characterised by a number of specific traits: presenting a variety of content, types, forms, methods of training; being more open; being client-oriented, or consumer-oriented, the latter not being made to adapt to available services, but, on the contrary, the educational sphere supplying the services required by the customer; guaranteeing the quality of the services provided; featuring high competition among various service types; introducing a value estimation of services (tuition fees) [6].

Many scholars note that the changes in the standing and role of education by the early 21 st century were brought about by powerful developments in the informatisation of education, employing modern information technology in the education sphere, as well as the requirement that the individual today should continually progress in the changing world of information [7].

Now we have approached one more essential attribute of contemporary civilisation processes, that is, widespread education through informatisation of the society. In all the industrially developed countries education becomes a need for self-education in the society of today. Self-education is a determinative factor for the development of an individual today and the society on the whole.

Human social life has accumulated quite a lot of contradictions. The world faces the survival dilemma today; global civilisation demands constructive interaction of nations. Global education is one of the factors of this interaction $[8,9]$.

Humankind has reached many summits in various fields of science and industry, it is exploring space and using contemporary technologies to create favourable living conditions on Earth. At the same time we witness a reverse process, and there arises a problem of spiritual, 
environmental, informational, military and other types of humankind safety. Global problems existing on Earth today worry us. This is where the primary contradiction of the century is hidden: the planetary civilisation is highly developed, but at the same time humankind is on the verge of extinction. This is the contradiction of our times, which no other preceding generation has known. The main mission of the global education is to call every human, every denizen of the planet Earth to solve this contradiction.

Civilisational development of nations should attest to the fact that the standing of education is improving. However, today a world-wide education crisis is believed to be taking place. The issues mentioned include lack of spirituality, devaluation of values, national nihilism, lack of professionalism, narrow specialisation, graduates' inability to adapt to the social conditions of their society, debates between proponents of classical education and vocational training, limited human facilities for mutual understanding and cooperation, and so on.

The contradictions between the education of today being aimed at the masses and the necessity of training elite specialists in scientific and engineering fields as well as in liberal arts, between curricula filled with abstract theory and economics and industry needing specific utilitarian knowledge, between STEM specialisations being in demand and young people not being that much interested in them have led to reforms and upgrades in education systems of many countries. It is obvious that every country has its own internal reasons for crises and other phenomena in education at a given stage of its historical development; however, there also exists a common reason behind this worldwide education crisis. According to contemporary researchers, this reason is the fact that education cannot meet new social and general human demands anymore. This means that we need to specify priority directions in education according to the requirements of the human being and the society.

\section{EDUCATION POLICY STRATEGY}

While developing conceptual approaches as part of the education policy of the 21 st century along with the concept of national and global, regional and local education, we should determine the priorities in the professional activity of specialists in the sphere of education and rearing of a Human Being.

The education policy strategy in the early 3rd millennium is committed to an Individual, meaning that it should ensure:

- - humane treatment of the individual as a holistic person, and of his or her natural peculiarities (health, capability for thought, feelings);

- - development of social properties of a person (being a citizen, a family member, a worker);

- - improvement of those personal qualities that allow the individual to exist as a subject of culture (spirituality, creativity, freedom, humanity).

Commitment to the Society means that the social consciousness should be directed onto the scale of spiritual and moral values primarily through education and upbringing.

This is exactly the goal that should become a priority in the professional activity of a specialist in the sphere of education. This goal leads us to designating the methodological aspect of shaping an individual in the $21 \mathrm{st}$ century, according to which education professionals should be trained, in our opinion.

The philosophy of education in the new century is built around the demands posed to the individual as a representative of the world community, a specific society, ethnicity and culture, a particular social and professional group and as an individual per se. Philosophical models of a human being of the new century emphasize the following characteristics: a high level of self-awareness, determining the meaning of life and one's own place in this world and the role played in preserving this world, organic interaction with the environment, and an active attitude towards making ideals a reality.

We can name the following primary priority directions of educational activity in the early 21 st century in Russia: increasing the role of culture studies, creating a competitive human potential capable of developing professionally not just in the Russian Federation but on the global scale, informatisation and environmentalisation of the sphere of education, globalisation of high-quality education, increasing the role of technology in educational processes [10].

Educational activity implies a purposeful and active attitude towards social being, the content of which is cognition and transformation of reality and creating the conditions necessary for one's existence. Educational activity discovers the nature and essence of an individual, and harmonises the social being with its drives, needs, interests and goals. The subjective personal world is deployed in the objective external world through educational activity. Voltaire allegedly wrote: "A human being is made for action. Not to act and not to exist is the same for a human being". Being passive is a negative characteristic of an individual who does not present oneself as an agent and thus does not exist.

Educational activity is a form, that is, a method, of being for an individual in the society. The content of it is a purposeful, conscious alteration and transformation of the social being, harmonising it with the intention of the individual-as-a-subject. The object of the activity is a single object, a set of objects or the social being on the whole. Same, social phenomena, processes and institutes become objects of activity. For an individual seen as a subject of educational activity, social being is raw material that should be subjected to alteration in order to obtain a new, more acceptable form and characteristics.

All activity is a unity of objectivation and desobjectivation. Objectivation is the process of implementing the essential powers of a human being (his or her energy, ideas, intentions, images and so on) in something external, like actions, things and other forms. Desobjectivation is the discovery and appropriation of the 
content, meaning, skills and experience already existing in the cultural values created by humankind. Educational activity is a whole system the foundation of which is the intention, that is, the goal of an individual. Various aspects of educational activity as a system may be considered, such as

- $\quad$ self-disclosure, self-fulfillment and self-actualisation of an individual in the world. The concept of "unwanted" personality points to the fact that this self-actualisation may fail for objective or subjective reasons;

- as a means of appropriating the "alien" world created by other people, embodied in and represented by forms of spiritual and material culture in a given society;

- as a way of resolving the contradictions between the individual and the outside world, when as a result the imaginable becomes real and the impossible turns possible [11].

During educational activity an individual tries to materialise their personal demands, goals and ideals, establish their power over the environment and sometimes even over other people. This activity forms the spiritual and moral aspects of personality, and how rich the personality is directly depends on how rich the content of this activity is. Educational activity helps the individual to improve the social being and expand its boundaries, to make their life meaningful and fill it with integrity [12].

Educational activity of an individual is a breakthrough, an escape of their creative, constructive essence. During educational activity it performs as a creative, originative creature that strives to push the envelope of the available reality. Educational activity of an individual in its substantial aspect is creation of human life in all its meanings and shades. This is why educational activity may also be defined as activity over the course of which the individual creates him- or herself as well by determining future plans and the conditions of his or her existence [13].

Educational activity is a highly dynamic system which is characterised by continual transformations, which, to quote A. N. Leontiev, are the essential distinguishing attributes of educational activity [14]. Transformation of educational activity is directly connected to the "cardinal problem of reforming education, namely transforming its means and methods of actualisation, harmonising them with the changing needs of the society and the individual, as well as the latest achievements of natural sciences and liberal arts. The key task here is updating the content of education» [15].

\section{CONCLUSION}

Transformation of educational activity is one of the primary stages in upgrading the system of education. This is a purposeful and controlled process of qualitative valuebased structural transformation of an existing system of education, the result of which is creating favourable conditions for activities of an individual. Transformation of educational activity is a successive connection and an objective trend in social development, legitimately related to the socialisation of an individual and characterised by the interpenetration of educational activity elements into any other activity the specifics of which concerns transferring knowledge and forming specific skills and abilities, which transforms a standard type of activity into an individual activity style [16].

The essence of this transformation of educational activity in a continuous learning system takes into account the following factors: regionalisation, humanisation, increasing the role of liberal arts, social and pedagogic methods and principles of social work, as well as ensuring connections to the respective cultural traditions of the nation and its type of spirituality.

The primary functionality of the transformation of educational activity lies in the change in the way of being of a person: he or she gets access to the experience of other subjects, entities, groups and is allowed to adjust the form of his or her activity and behaviour in accordance with the social and cultural situation and activity microenvironment, as well as obtaining new knowledge as regards one's social experience and personal cultural level. The person finds assessment of their abilities through the lens of the cultural values appropriated.

The principles of transformation of educational activity are identical to the principles of continuous learning:

- continuity of a holistic education process;

- taking needs, interests and values of the society, nation, ethnic group and individual into account;

- scientific conceptualisation of social and cultural experience;

- simulating pedagogic technologies and situations;

- accounting for the level of development of social and individual consciousness and self-awareness;

- cultural revival.

Transformation of educational activity will make it possible to detect specific trends, patterns and connections in the field of education policy of the state or a specific educational institution.

\section{REFERENCES}

[1] Lartsev V. S. Social and cultural determinants of personality formation: Monograph. Kiev, Print-Ekspress. 2002.

[2] Ivlev Yu. V., Ivlev V.Yu., Ivleva M.L. Logical-argumentative basics of educational culture // Proceedings of 4th International Conference on Education, Language, Art and Intercultural Communication (ICELAIC 2017) Part of the series ASSEHR. Moscow, Russia. Pp. 173-177.

[3] Lazarev F.V., Lebedev S.A. The Philosophical Reflex: Essence, Form Types // Voprosy filosofii. 2016. No. 6. Pp. 15-28.

[4] Maykova V. P., Molchan E. M. Spirituality as a factor of social system stability // Bulletin of the Moscow Region State University. Series: Philosophical Sciences, 2017. No. 1. Pp. 46-54. 
[5] Shannon C. Works on the information theory and cybernetics. Moscow, Foreign Literature Publ., 1963 (in Russian).

[6] Berkut V. P., Bondareva Ya. V., Maykova V. P., Molchan E. M., Pesotskiy V. A. Methodological and axiological approaches to solving the problems of consolidating the society in the globalisation age // Novosibirsk State Pedagogical University Bulletin. 2018, vol. 8, no. 1. Pp. 138-158.

[7] Komissarov I; Nekhamkin V. The Models of Historical Cognition: Current Status and Prospects of Development // Journal of Education and Science "ISTORIYA". 2017. Vol. 8. No. 2. DOI: 10.18254/S0001779-5-1

[8] Maykova V. P. Pedagogics methodology and the environmentalist point of view // Sotsialno-gumanitarnye znaniya (Social and liberal arts knowledge). 2013. No.1. Pp. 289-298.

[9] Gubanov N.I., Gubanov N.N. Global mentality as a pre-condition of civilizations' conflict prevention // Sotsiologicheskie issledovaniya. 2011. № 4. P. 51-58.

[10] Suzdaleva T.R. Migratory processes in the context of geopolitics // Vestnik Tomskogo gosudarstvennogo universiteta-Filosofiyasotsiologiya-politologiya-Tomsk state university journal of philosophy sociology and political science. 2016. № 3 (36). P. 237244. DOI: $10.17223 / 1998863 X / 35 / 25$.

[11] Savchenko E. A. Anthropoculturological paradigm: raising a civilised person. Monograph. 2nd edition. Moscow, International Academy of Pedagogical Education Sciences, Moscow Region State University; Yaroslavl, Kantsler. 2016.

[12] Ivleva M.L., Ivlev V.Yu. Principal approaches of modern psychology to constructing giftedness // "Proceedings of the 2017 2nd International Conference on Contemporary Education, Social Sciences and Humanities". (ICCESSH 2017). Part of the series ASSEHR. Moscow, Russia. V.124. Pp.1176-1180

[13] Slobodchikov V. I. New image of Russian education in the 21st century // Language and topical issues of education: Proceedings of the International Scientific and Applied Conference, December 15th, 2016, Moscow / E. I. Artamonova, O. S. Ushakova, ed. Moscow, International Academy of Pedagogical Education Sciences. 2017. Pp. 46-48.

[14] Leontev A. N. Activity. Consciousness. Personality. Moscow, State Publishing House of Political Literature. 1975.

[15] Savchenko E. A. Educational activity as a social and cultural phenomenon (a theoretical and methodological analysis): Monograph. Bryansk, Bryansk State University. 2005.

[16] Molchan E. M. Transformation of educational activity as a social and cultural phenomenon // Methodology in science and education: Proceedings of the Russian conference of universities and academic instituions of Russian Academy of Sciences. Moscow, March 30th31st, 2017. / Bauman Moscow State Technical University. Federal Research Center for Computer Science and Control of Russian Academy of Sciences. - Moscow, Bauman Moscow State Technical University. 2017. Pp. 210-212. 